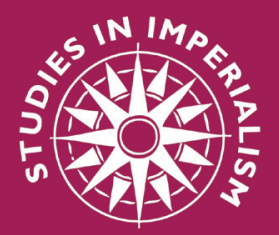

\title{
EMIGRANTS AND EMPIRE
}

\section{British Settlement in the Dominions Between the Wars}

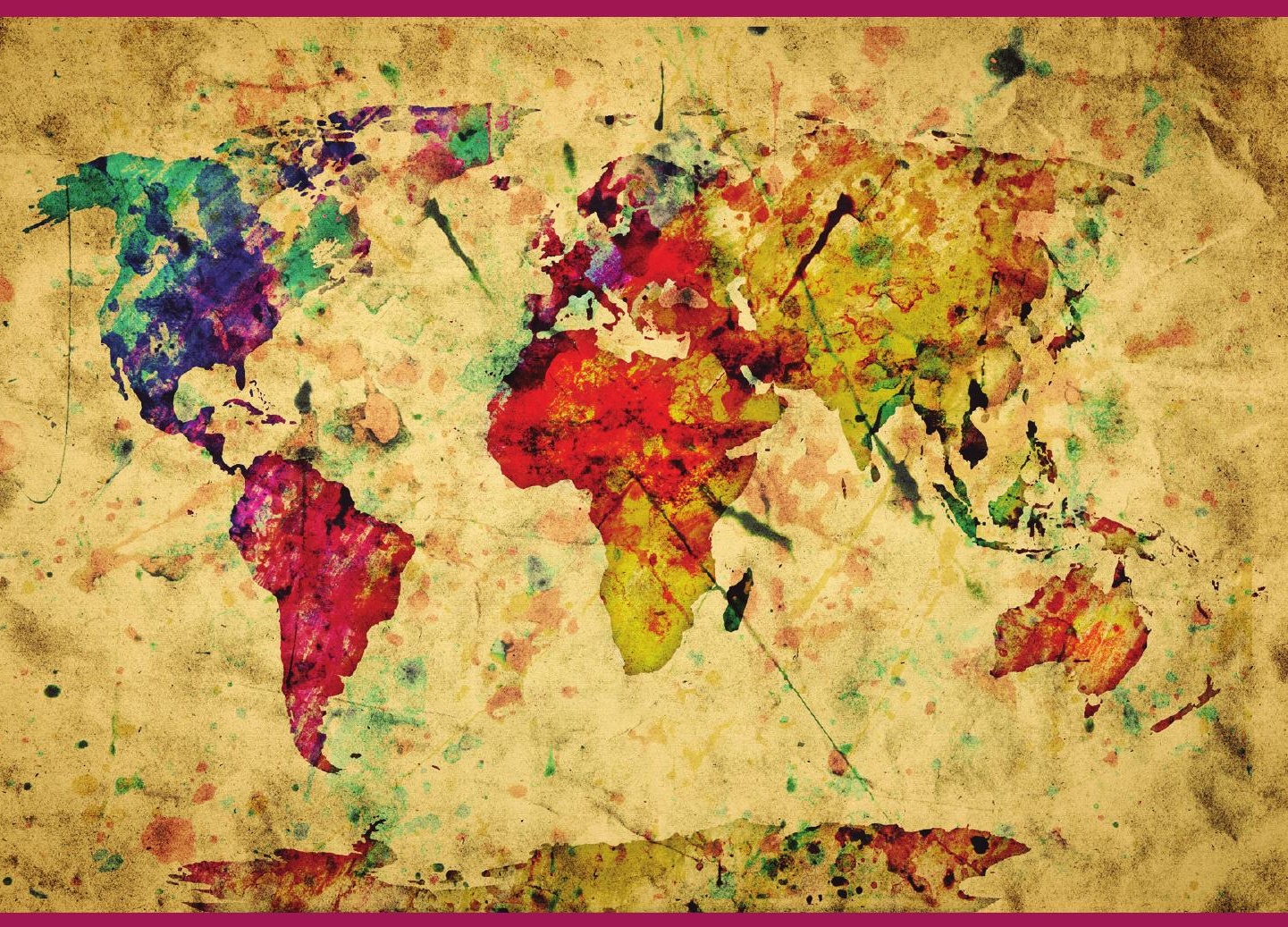




\section{IMPERIALSINM}

general editor John M. MacKenzie

When the 'Studies in Imperialism' series was founded by Professor John M. MacKenzie more than thirty years ago, emphasis was laid upon the conviction that 'imperialism as a cultural phenomenon had as significant an effect on the dominant as on the subordinate societies'. With well over a hundred titles now published, this remains the prime concern of the series. Cross-disciplinary work has indeed appeared covering the full spectrum of cultural phenomena, as well as examining aspects of gender and sex, frontiers and law, science and the environment, language and literature, migration and patriotic societies, and much else. Moreover, the series has always wished to present comparative work on European and American imperialism, and particularly welcomes the submission of books in these areas. The fascination with imperialism, in all its aspects, shows no sign of abating, and this series will continue to lead the way in encouraging the widest possible range of studies in the field. Studies in Imperialism is fully organic in its development, always seeking to be at the cutting edge, responding to the latest interests of scholars and the needs of this ever-expanding area of scholarship. 


\section{IMPURIES IN-}

PROPAGANDA AND EMPIRE

The manipulation of british public opinion, 1880-1960 john m. Mackenzie

Imperialism and popular culture

ed. John M. Mackenzie

Ephemeral vistas

The Expositions Universelles, Great exhibitions and World's Fairs, 1851-1939 Paul greenhalgh

'At duty's call'

A study in obsolete patriotism W.J. Reader

Images of the army

The military in British art, 1815-1914 j. W. M. Hichberger

The empire of nature

Hunting, conservation and British Imperialism

John M. Mackenzie

'Benefits bestowed?

Education and british imperialism ed. J. A. Mangan

Imperial medicine and indigenous societies

ed. David Arnold

Imperialism and juvenile literature

ed. Jeffrey Richards

Asia in western fiction

ed. Robin W. Winks and James R. Rush

Empire and sexuality

The British experience Ronald M. Hyam

Imperialism and the natural world

ed. John M. MacKenzie

Emigrants and empire

British settlement in the Dominions

between the wars ed. Stephen Constantine

Making imperial mentalities

Socialisation and British imperialism ed. J. A. Mangan 


\section{Emigrants and Empire}

British Settlement in the Dominions

Between the Wars

edited by Stephen Constantine

MANCHESTER UNIVERSITY PRESS

Manchester 
Whilst copyright in the volume as a whole is vested in Manchester University Press, copyright in individual chapters belongs to their respective authors, and no chapter may be reproduced wholly or in part without express permission in writing of both author and publisher.

Published by Manchester University Press

Altrincham Street, Manchester, M1 7ja, Uk

www.manchesteruniversitypress.co.uk

British Library cataloguing in publication data

Constantine, Stephen

Emigrants and empire: British settlement in the dominions between the wars.

(Studies in imperialism).

1. Great Britain. Emigration to Commonwealth countries, history. Commonwealth countries. Immigration from Great Britain, history

I. Title II. Series 304.80941

Library of Congress cataloging in publication data

Emigrants and empire: British settlement in the dominions between the wars / edited by Stephen Constantine.

p. cm. - (Studies in imperialism)

ISBN 0-7190-3011-0

1. Great Britain-Emigration and immigration-History-20th century. 2. Great Britain-Colonies-Emigration and immigration-History-20th century.

I. Constantine, Stephen. II. Series: Studies in imperialism (Manchester, England) JV7615.E45 1990 325'.241'09171241—dc20 89-77464

ISBN 0-7190-3011-0 hardback

The publisher has no responsibility for the persistence or accuracy of URLs for any external or third-party internet websites referred to in this book, and does not guarantee that any content on such websites is, or will remain, accurate or appropriate.

Photoset in Linotron Trump Mediaeval by Northern Phototypesetting Co Ltd, Bolton 